\title{
Relationship of Obesity and Peak Expiratory Flow Rate (PEFR) amongst 8-15 Years Old School Children
}

\author{
DELOWAR HOSSAIN ${ }^{1}$, SELINA KHANUM ${ }^{2}$, CHOUDHURY ALI KAWSER ${ }^{3}$
}

\begin{abstract}
Background: Obesity is rapidly escalating worldwide in all age groups. Childhood obesity is associated with a greater long-term risk of hypertension and type 2 diabetes mellitus in adulthood.
\end{abstract}

Objectives: To observe the relationship of peak expiratory flow rate (PEFR) with obesity.

\begin{abstract}
Methods: Two hundred students were selected from two different schools of Narayanganj city by following inclusion criteria- for group A: BMI of $>95$ th percentile for age and sex was taken as -obese and for group B: BMI of 10th- 85th percentile for age and sex was taken as non-obese. The anthropometric measurements and PEFR were measured by standard procedure.
\end{abstract}

Results: PEFR were found statistically significant in non-obese than obese groups $(p<0.05)$ in the following variables-height, weight, BMl and age. The stronger correlation was with $\mathrm{BMI}$, weight and height $(P<0.001)$ and lesser correlation was with age $(<0.05)$

Conclusion: This study PEFR significant positive correlation with non-obese than obese children.

Keywords: Obese, non-obese, PEFR, BMI.

\section{Introduction}

Childhood and adolescence over weight and obesity have become a major public health problems both in westernized and more recently in developing countries. ${ }^{1,2}$ About $15-20 \%$ of body fat for men and $25 \%$ of body fat for women are generally accepted as 'normal', but 10 to $20 \%$ of excess body fat over the usual values is generally considered to be "obesity". ${ }^{3}$ Childhood obesity is a global issue with an estimated 1 in 10 school aged children are being obese. ${ }^{4}$ South Asians generally have a higher level of fat per unit of BMI compared to Whites. ${ }^{5}$ Indian males were at higher risk of being overweight than white British males and the prevalence of obesity and overweight was similar in white British and Bangladeshi males. ${ }^{5}$ In the United States, approximately $60 \%$ of adults and one in four children and adolescents can be classified as overweight or obese. In India, school-based data

1. Assistant Professor, Department of Pediatric Nephrology, MAG Osmani Medical College, Sylhet.

2. Professor, Department of Pediatric Pulmonology, BSMMU, Dhaka.

3. Professor, Dept. of Paediatrics, BSMMU, Dhaka Correspondence: Dr. Md. Delowar Hossain, Email: jubayer_ tasfea @yahoo.com indicate a prevalence of obesity ranging between $5.6 \%$ and $24 \%$ in children and adolescents. ${ }^{6}$ Overweight and obese persons are at risk of a number of medical conditions which can lead to further morbidity and mortality. ${ }^{7}$ Obese people are at increased risk of respiratory symptoms, such as breathlessness, particularly during exercise, even if they have no obvious respiratory illness. Obesity has a clear potential to have a direct effect on respiratory wellbeing, since it increases oxygen consumption and carbon dioxide production, while at the same time it stiffens the respiratory muscles, decrease PEFR and increases the mechanical work of breathing. ${ }^{8}$ PEFR(Peak expiratory flow rate) is influenced by gender, body surface area, obesity, physical activity posture, environment \& racial differences. ${ }^{9-12}$ and also by individual's physical effort. This article is mainly focused to be concerned with the effect of obesity on PEFR. The elementary factors upon which PEFR values depend are voluntary effort, strength of the expiratory muscles, generating the force of contraction, lung volume, airway size and elastic recoil strength of the lungs. ${ }^{10,12-14}$ Height, weight and chest circumference are the main determinant factors of 
PEFR among the physical parameters. ${ }^{15,16}$ Several studies support the association already been reported that PEFR lower in obese children. ${ }^{4}$

The present study was aimed to find out the relationship of obesity with PEFR among school children.

\section{Materials and Methods}

It was a cross sectional study, done in two schools by the Department of Paediatrics, Bangabandhu Sheikh Mujib Medical University (BSMMU), Dhaka. Study period was from January 2009 to December 2010. Total two hundreds obese and non-obese between 8- 15 years old school children both male and female were selected purposively and grouped into Group A (case group) 100 obese school children and Group B (control group) 100 non-obese school children. In both groups study populations were matched in regards of different variables. BMI of $>$ 95th percentile for age and sex was taken as obese and BMI of 10th- 85th percentile for age and sex was taken as non-obese. Informed consent was obtained from the parents of children who were participated in this study. Exclusion criteria for both groups were medical history of atopy and asthma, pectus carinatum, pectus excavatum, kyphosis, scoliosis, heart disease with obesity. Arribs International school and Ideal school of Narayanganj City Corporation was sample collection site. Initial sample were 221. Out of them 21 students were excluded from the present study as 09 had family history of asthma, 03 had congenital anomaly in the chest, 02 had congenital heart disease, 07 were underweight as they were not performing forceful breathing. At first all subjects were evaluated by physical examination and their Anthropometric parameters like height in centimeters, weight in kilo grams were measured. BMI were calculated by weight in $(\mathrm{kg}) /$ height in meter square. First of all it was shown to them how to hold the peak flow meter without obstructing the movement of indicator, and then it was shown them how to take deep breath in and to blow out by forceful expiration. Three such readings were obtained from each child. The highest value obtained were taken as Peak Expiratory Flow Rate (PEFR). ${ }^{24,25}$

The relevant data were collected in the computer and statistical analysis were done by using software package SPSS for Windows, version 13.0 (SPSS Inc., Cin Chicago, IL, USA) The entire data were tabulated and the values were expressed in (Mean \pm SD). The correlation between PEFR (Measured) and Height, Weight, BMI were analyzed by using Pearson Correlation.
Prior to the commencement of this study, the research protocol was approved by the thesis committee (Local Ethical Committee). Ethical commitment was followed accordingly. This study was not based on any thesis or dissertation.

\section{Results}

The following parameters were measured and the results were expressed as follows: Baseline characters of the subjects were Height, Weight, BMI and PEFR.

The Mean $( \pm$ SD) of height, weight, BMI and PEFR of Group-A and Group-B were $146.54( \pm 11.22) \mathrm{cm}$ and $145.62( \pm 8.97) \mathrm{cm}, 58.33( \pm 16.10) \mathrm{kg}$ and 41.52 $( \pm 8.51) \mathrm{kg}, 26.58( \pm 3.79) \mathrm{kg}$ and $18.77( \pm 1.80) \mathrm{kg}, 400.4$ $( \pm 112.9) \mathrm{L} / \mathrm{min}$ and $442.4( \pm 103.0) \mathrm{L} / \mathrm{min}$ respectively. $P$ value of height of both groups were not significant $(p>.05)$ but significant in weight, BMI and PEFR $(p<.05)$ Table-l.

In relation to different height interval $120-130 \mathrm{~cm}, 131$ $140 \mathrm{~cm}, 141-150 \mathrm{~cm}, 151-160 \mathrm{~cm}, 161-170 \mathrm{~cm}$ Mean $( \pm S D)$ of PEFR in group=A and group-B were $266( \pm$ $35)$ and $313( \pm 29) \mathrm{L} / \mathrm{min}, 327( \pm 55)$ and $366( \pm 61) \mathrm{L} /$ $\mathrm{min}, 385( \pm 64)$ and $440( \pm 73) \mathrm{L} / \mathrm{min}, 462( \pm 111)$ and $517( \pm 68) \mathrm{L} / \mathrm{min}, 543( \pm 89)$ and $638( \pm 85) \mathrm{L} / \mathrm{min}$ respectively (table 2 ). There was statistically significantly higher PEFR $(p<0.05)$ in non-obese compared to obese group in all height categories (Table-II).

In relation to different weight interval $40 \mathrm{~kg}, 41-50 \mathrm{~kg}$, $51-60 \mathrm{~kg},>61 \mathrm{~kg}$, Mean $( \pm S D)$ was done between independent variables (Height, Weight, BMl and age) and dependent variable PEFR. PEFR in group $=A$ and group-B were $283( \pm 52)$ and $383( \pm 76) \mathrm{L} / \mathrm{min}, 330$ $( \pm 63)$ and $487( \pm 81) \mathrm{L} / \mathrm{min}, 407( \pm 43)$ and $525( \pm 91) \mathrm{L} /$ min, $472( \pm 110)$ and $626( \pm 125) \mathrm{L} / \mathrm{min}$ respectively. There was significant difference in PEFR between obese and non-obese group in all weight category $(p<0.001)$-Table-III.

PEFR was positively correlated with different height interval in non- obese than-obese group. Pearson's correlation $r$ values were 0.719 and 0.758 in obese and non-obese group respectively.

PEFR was more positively correlated with weight in non- obese than-obese group. Pearson's correlation $r$ values were 0.657 and 0.616 and $p$ values were 0.001 and 0.001 in obese and non-obese group respectively.

(BMI): PEFR positively correlated with BMI in nonobese than obese group. Correlation $r$ values were 0.449 and 0.616 and $p$ values were 0.001 and 0.001 in obese and non-obese group respectively (Fig.-1). 
Table-I

Distribution of anthropometry and PEFR by groups $(n=100)$

\begin{tabular}{lccc}
\hline Parameters & Group-A (Obese) & Group-B (Non-Obese) & p value \\
& Mean $( \pm$ SD $)$ & Mean $( \pm$ SD $)$ & $0.523 \mathrm{~ns}$ \\
\hline Height $(\mathrm{cm})$ & $146.54( \pm 11.22)$ & $145.62( \pm 8.97)$ & $0.001^{* * *}$ \\
Weight $(\mathrm{kg})$ & $58.33( \pm 16.10)$ & $41.52( \pm 8.51)$ & $0.001^{* * *}$ \\
BMl & $26.58( \pm 3.79)$ & $18.77( \pm 1.80)$ & $0.007^{* *}$ \\
PEFR(L/min) & $400.4( \pm 112.9)$ & $442.4( \pm 103.0)$ & \\
\hline
\end{tabular}

Data were expressed in Mean $\pm S D$.Statistical analysis was done by $t$ test. $n s=$ non significant, ${ }^{* *}$ Significant

Table-II

Distribution of different height intervals and PEFR by groups $(n=100)$

\begin{tabular}{|c|c|c|c|c|c|}
\hline \multirow[t]{2}{*}{ Height interval (cm) } & \multicolumn{3}{|c|}{ Group-A (Obese) } & Group-B (Non-Obese) & \multirow[t]{2}{*}{ p value } \\
\hline & $\mathrm{N}$ & $\operatorname{PEFR}$ Mean $( \pm S D)(L / m i n)$ & $\mathrm{N}$ & $\operatorname{PEFR}$ Mean $( \pm S D)(L / m i n)$ & \\
\hline $120-130$ & 11 & $266( \pm 35)$ & 06 & $313( \pm 29)$ & $0.014^{\star *}$ \\
\hline $131-140$ & 20 & $327( \pm 55)$ & 27 & $366( \pm 61)$ & $0.031^{* *}$ \\
\hline $141-150$ & 30 & $385( \pm 64)$ & 38 & $440( \pm 73)$ & $0.002^{* *}$ \\
\hline $151-160$ & 27 & $462( \pm 111)$ & 23 & $517( \pm 68)$ & $0.043^{* *}$ \\
\hline $161-170$ & 12 & $543( \pm 89)$ & 06 & $638( \pm 85)$ & $0.047^{* *}$ \\
\hline
\end{tabular}

Data were expressed in Mean $\pm S D$. Statistical analysis was done by t- test.

Table-III

Distribution of different weight and PEFR in by groups $(n=100)$

\begin{tabular}{lccccc}
\hline Weight(kg) & N & $\begin{array}{c}\text { Group-A(Obese }) \\
\text { PEFRMean }( \pm S D)(L / m i n)\end{array}$ & $N$ & $\begin{array}{c}\text { Group-B(Non-Obese) } \\
\text { PEFRMean }( \pm S D)(L / m i n)\end{array}$ & p value \\
\hline$<40$ & 13 & $283( \pm 52)$ & 51 & $383( \pm 76)$ & $0.001^{* *}$ \\
$41-50$ & 27 & $330( \pm 63)$ & 36 & $487( \pm 81)$ & $0.001^{* *}$ \\
$51-60$ & 14 & $407( \pm 43)$ & 10 & $525( \pm 91)$ & $0.001^{* *}$ \\
$>61$ & 46 & $472( \pm 110)$ & 3 & $626( \pm 125)$ & $0.025^{*}$ \\
\hline
\end{tabular}

Data were expressed in Mean $( \pm S D)$. Statistical analysis was done by t- test.

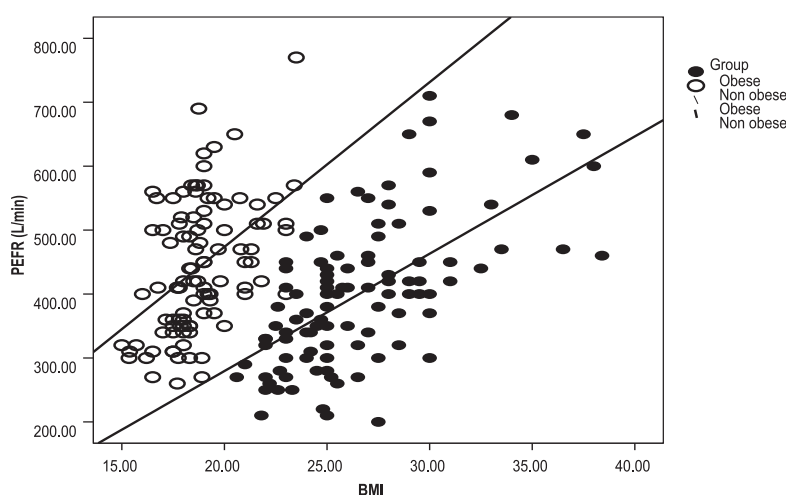

p values are 0.001 (obese) and 0.001 (non-obese) r-values are 0.449(obese) and0.616(non-obese)

Fig.-1: Correlation of BMI with PEFR $(n=100)$

\section{Discussion}

Obesity as a health risk needs no introduction in the present global scenario. ${ }^{5}$ However, treatment for childhood obesity remains largely ineffective..$^{5,6,15}$ In the present study, there was statistically significant difference in weight, BMI and PEFR between the groups $(p<0.05)($ Table-I). In a study measured PEFR of 1023 urban Nigerian children aged 6-12 years showed significant correlation with the various anthropometric parameters, height having the best correlation. ${ }^{21}$ In this study non obese groups height, weight and BMI were significantly correlated with PEFR ( $p<0.001, r=.710$ ) (Fig.-1) than obese groups. In another study showed that positive correlation was 
seen between age, height, weight and PEFR. ${ }^{16}$ In a separate study 339 British schoolchildren aged 7-16 years found a strong correlation between PEFR and height. ${ }^{15}$ Height and BSA (Body surface area) were found to be better predictors of PEFR than the other parameters. In present study PEFR of non-obese group showed significantly higher in all height category $(p<0.05)$ (Table-I, Table-II) than obese group. Although sample size was calculated statistically; the original sample size was small in relation to huge number of population. So more studies are require in this field.

\section{Conclusion}

This study PEFR shown significant positive correlation with non-obese than obese children.

\section{Recommendation}

For precise result of the present study, further study with large sample size involving multiple centers is the recommendation of this study. Awareness program for the healthy life style to prevent childhood obesity.

\section{References}

1. Morandi A, Meyre D, Lobbens S, Kleinman K, Kaakinen M. Estimation of Newborn Risk for Child or Adolescent Obesity: Lessons from Longitudinal Birth Cohorts. PLOS: 2012; 7 : e49919.

2. Weker H. Simple obesity in children.A study on the role of nutritional factors. Medycyna Wieku Rozwojowego 2006;10:3-191.

3. Gibson LJ, Peto J, Janet M Warren JM, Silva IdosS. Lack of evidence on diets for obesity for children: a systematic review. Int J Epidemiol December 2006; 35:1544-52.

4. Lobstein T, Baur L, Uauy R. Obesity in children and young people: a crisis in public health. Obes Rev 2004; 5: S4-S85.

5. Guh DP, Zhang W, Bansback N, Amarsi Z, Birmingham $\mathrm{CL}$, Anis $\mathrm{AH}$. The incidence of comorbidities related to obesity and overweight:A systematic review and meta-analysis. BMC Public Health 2009; 9:88.

6. Paralikar SJ, Kathrotia RG, Pathak NR, Jani MB. Assessment of pulmonary functions in obese adolescent boys. Lung India 2012;29:236-40.

7. Cottam DR, Mattar SG, Barinas-Mitchell E, Eid G, Kuller L, Kelley DE et al. The chronic inflammatory hypothesis for the morbidity associated with morbid obesity: implications and effects of weight loss. Obesity Surgery 2004; 14:589-600.

8. Dungel KU, Parthasarathy D, Dipali S.Peak expiratory flow rate of Nepalese children and young adults. Kathmandu University Medical Journal 2008;6:346-54.

9. Rangnathan S, Li C, Wood L, Rangnathan G, "Adipose tissue tumor necrosis factor and interleukin- 6 expression in human obesity and insulin resistance". American Journal of Physiology and Endocrinology Metabolism 2001; 280:745-51.

10. Shaheen SO, Sterne JAC, Montgomery SM, Azima HA. "Birth weight, body mass index and asthma in young adults". Thorax 1999; 54: 396402.

11. Gianinis HH, Bianca O, Collins LC, Hoberty PD, Walker JF, Fletc her EC, et al. "The effects of body fat distribution on pulmonary function tests", Chest 1995; 107: 1298-1302.

12. Raju PS, Prasad KV, Ramana YV, Murthy KJ. "Pulmonary function Tests in Indian girls prediction equations". Indian Journal of Pediatrics 2004;71:893-97.

13. Salome CCM, King GGG, Berend $N$. "Physiology of obesity and effects on lung function". Journal of Applied Physiology 2006; 108: 11.

14. Onadeko BO, Falase AO, Ayeni O. "Pulmonary function studies in sports - men. African Journal of Medicine and Science 1976; 5: 291-95.

15. Jaja SI, Ojo GO. Peak flow rate in young Nigerian adults. Nigerian Journal of Physiological Sciences 1983; 1: 24-30.

16. Mungreiphy NK. Ethnicity obesity and health pattern among Indian population. Journal of Natural science, Biology and Medicine 2012; 3: 52-59.

17. Salome CM, King GG, Berend N. Physiology of obesity and effects on lung function. Journal of Applied Physiology. 2010; 108: 206-11.

18. Malnick SD, Knobler $\mathrm{H}$. The medical complications of obesity. QJ Med 2006; 99: 565-79. 
19. The increase in the normal functioning of adipose tissue in obese subjects leads to a systemic proinflammatory state. (WHO Obesity, 1998).

20. Agaba PA, Thacher TD, Angyo IA, Agaba El. Peak expiratory flow rates in healthy Nigerian children. Journal of Tropical Pediatrics 2003;49:157-59.

21. Mohammadzadeh I, Gharagozlou M, Fatemi SA. Normal Values of Peak Expiratory Flow Rate in Children from the Town of Babol, Iran. Iranian Journal of Allergy, Asthma and Immunology 2006; 5: 195-98.

22. Seo WH, Ahn SH, Park SH, Kim J, Ahn KM, Ko $\mathrm{BJ}$, et al. The standard range of peak expiratory flow rates of Korean children. Asian Pac J Allergy Immunol 2011; 29:143-49.

23. Udupihille M. Peak expiratory flow rate in Sri Lankan schoolchildren of Sinhalese ethnic origin. Respiratory Medicine 1994;88:219-27.

24. Goswami B, Roy AS, Dalui R, Bandyopadhyay A." Peak Expiratory Flow Rate - A Consistent Marker of Respiratory Illness Associated with Childhood Obesity." American Journal of Sports Science and Medicine 2014; 21-26.

25. Sudha D, Chandra Selvi E, Saikumar P. Correlation of Nutritional Status and Peak Expiratory Flow Rate in Normal South Indian ChildrenAged 6 to 10 Years. IOSR Journal of Dental and Medical Sciences (JDMS) 2012; 2: 11-16. 